\title{
Factors Associated with the Complications of Hysteroscopic Myomectomy
}

\section{Fatores associados às complicações da miomectomia por histeroscopia}

\author{
Mariana Patelli Juliani de Souza Lima ${ }^{1}$ Lúcia Costa-Paiva1ำ Luiz Gustavo Oliveira Brito ${ }^{1}$ \\ Luiz Francisco Baccaro ${ }^{10}$ \\ ${ }^{1}$ Department of Obstetrics and Gynecology, Universidade Estadual de \\ Campinas (UNICAMP), Campinas, SP, Brazil \\ Address for correspondence Luiz Francisco Baccaro, MD, PhD, Rua \\ Alexander Fleming 101, Cidade Universitária Zeferino Vaz, Campinas, \\ SP, 13083-881, Brazil (e-mail: baccaro@unicamp.br).
} Rev Bras Ginecol Obstet 2020;42(8):476-485.

\begin{abstract}
Keywords

- uterine myomectomy

- leiomyoma

- myoma

- uterine hemorrhage

- intraoperative complications
\end{abstract}

Objective To evaluate the factors associated with complete myomectomy in a single surgical procedure and the aspects related to the early complications.

Methods A cross-sectional study with women with submucous myomas. The dependent variables were the complete myomectomy performed in a single hysteroscopic procedure, and the presence of early complications related to the procedure.

Results We identified 338 women who underwent hysteroscopic myomectomy. In $89.05 \%$ of the cases, there was a single fibroid to be treated. According to the classification of the International Federation of Gynecology and Obstetrics (Fédération Internationale de Gynécologie et d'Obstétrique, FIGO, in French), most fibroids were of grade $0(66.96 \%)$, followed by grade $1(20.54 \%)$, and grade $2(12.50 \%)$. The myomectomies were complete in $63.31 \%$ of the cases, and the factors independently associated with complete myomectomy were the diameter of the largest fibroid (prevalence ratio [PR]: 0.97 ; $95 \%$ confidence interval [95\%Cl]: $0.96-0.98)$ and the classification 0 of the fibroid according to the FIGO (PR: 2.04; 95\% CI: 1.18-3.52). We observed early complications in $13.01 \%$ of the hysteroscopic procedures (4.44\% presented excessive bleeding during the procedure, $4.14 \%$, uterine perforation, $2.66 \%$, false route, $1.78 \%$, fluid overload, $0.59 \%$, exploratory laparotomy, and $0.3 \%$, postoperative infection). The only independent factor associated with the occurrence of early complications was incomplete myomectomy (PR: $2.77 ; 95 \% \mathrm{Cl}: 1.43-5.38$ ).

Conclusions Our results show that hysteroscopic myomectomy may result in up to $13 \%$ of complications, and the chance of complete resection is greater in small and completely intracavitary fibroids; women with larger fibroids and with a high degree of myometrial penetration have a greater chance of developing complications from hysteroscopic myomectomy.

\section{Resumo}

Objetivo Avaliar os fatores associados a miomectomia por histeroscopia completa em um único procedimento e as suas complicações. received

December 12, 2019

accepted

May 28, 2020
DOI https://doi.org/

$10.1055 / \mathrm{s}-0040-1713915$.

ISSN 0100-7203.
Copyright $\odot 2020$ by Thieme Revinter

Publicações Ltda, Rio de Janeiro, Brazil
License terms

(c) (i) 
Métodos Estudo de corte transversal com mulheres submetidas a histeroscopia para exérese de miomas submucosos. As variáveis dependentes foram a miomectomia completa realizada em um tempo cirúrgico único, e a presença de complicações precoces relacionadas ao procedimento.

Resultados Analisamos 338 mulheres que foram submetidas a miomectomia histeroscópica. Em $89,05 \%$ dos casos, o mioma a ser tratado era único. Quanto à classificação da Federação Internacional de Ginecologia e Obstetrícia (Fédération Internationale de Gynécologie et d'Obstétrique, FIGO, em francês), a maioria era de grau $0(66,96 \%)$, seguidos pelos graus $1(20,54 \%)$ e $2(12,50 \%)$. As miomectomias foram completas em $63,31 \%$ das mulheres, sendo que os fatores independentemente associados à miomectomia completa foram o diâmetro do maior mioma (razão de prevalência [RP]: 0,97; intervalo de confiança de 95\% [IC95\%]: 0,96-0,98) e a classificação FIGO grau 0 (RP: 2,04; IC95\%: 1,18-3,52). Foram observadas complicações precoces em $13,01 \%$ dos procedimentos (4,44\% apresentaram sangramento excessivo durante o procedimento, $4,14 \%$, perfuração uterina, $2,66 \%$, falso pertuito,

\section{Palavras-chave}

- miomectomia uterina

- leiomioma

- mioma

- hemorragia uterina

- complicações intraoperatórias $1,78 \%$, intoxicação hídrica, $0,59 \%$, laparotomia exploradora, e $0,3 \%$, infecção pósoperatória). O único fator independentemente associado à ocorrência de complicações precoces foi a realização de miomectomia incompleta (RP: 2,77 ; IC95\%: 1,43-5,38). Conclusão Nossos resultados mostram que as complicações da miomectomia por histeroscopia podem ocorrer em até $13 \%$ dos procedimentos. A chance de ressecção completa é maior em miomas pequenos e completamente intracavitários; mulheres com miomas maiores e com maior grau de penetração miometrial têm maiores chances de desenvolver complicações.

\section{Introduction}

Uterine fibroids are benign monoclonal tumors composed of smooth muscle cells mixed with different amounts of extracellular matrix, arising in the myometrium. ${ }^{1,2}$ Fibroids are the most frequent benign tumors in women of reproductive age, and the prevalence rates vary between $20 \%$ and $50 \%$. Although almost always benign ${ }^{5}$ and with a low rate of cell proliferation in vivo, they can lead to increased uterine bleeding, pelvic pain and infertility, ${ }^{3}$ depending on their size and location within the uterus. Submucosal myomas extend into the uterine cavity and can cause the greatest changes in the integrity of the endometrium and in the capacity of the myometrium to contract and stop the bleeding from the endometrial vessels. ${ }^{1}$

For women with submucosal myomas, myomectomy through hysteroscopy is an option that enables uterine preservation, ${ }^{6}$ and it is currently considered the procedure of choice for the treatment of this disease. ${ }^{7}$ Before the advent of hysteroscopy, many intrauterine diseases were treated with more invasive procedures, with greater risks and costs, such as laparotomy and hysterectomy, or less resolution, such as dilation and curettage. ${ }^{8}$ However, among the procedures that can be performed by hysteroscopy, myomectomy has one of the highest complication rates. ${ }^{9}$

The complications of surgical hysteroscopy can be divided into early and late. ${ }^{10}$ Among the early complications, excessive bleeding, uterine perforation, postoperative infection and fluid overload can be mentioned. Some studies ${ }^{11-14}$ report that early complications occur in $\sim 1.0 \%$ to $3.6 \%$ of the procedures. Regarding the late complications, uterine synechiae are the most frequent. ${ }^{10}$ An incomplete resection of a myoma is a suboptimal outcome. A study ${ }^{15}$ suggests that in $\sim 12 \%$ of the cases it is not possible to perform complete myomectomy in a single procedure, which can result in the exposure of the women to new risk in a subsequent procedure, in addition to resulting in more costs to health systems.

Knowing the factors associated with the complications of hysteroscopic myomectomy is important for an adequate therapeutic planning. In selected cases, the use of medications that decrease the volume of the fibroid prior to surgery, or strategies to facilitate cervical dilatation, may prevent multiple surgical procedures. With the objective of evaluating the factors associated with complete myomectomy in a single surgical procedure, and the aspects related to a higher frequency of early complications of hysteroscopic myomectomy, a retrospective study was conducted in a university hospital.

\section{Methods}

A cross-sectional study was performed, with collection of retrospective data, at Hospital da Mulher Professor Dr. José Aristodemo Pinotti-Centro de Atenção Integrada à Saúde da Mulher, Universidade Estadual de Campinas (CAISM/UNICAMP), including all women who underwent surgical hysteroscopy for the treatment of uterine fibroids from March 1st, 
2000 to July 31st, 2017. This hospital is responsible for the training of medical residents, and the surgical procedures are performed by the residents under direct supervision of the senior surgeon. All hysteroscopies were performed in a surgical center adequately equipped to perform the procedure. All procedures were performed under anesthesia, usually spinal block, supplemented or not by drugs with central hypnotic action. The technical steps were performed as recommended by references to perform surgical hysteroscopy. ${ }^{16}$ For women who underwent more than one surgical hysteroscopy, only the first procedure was included.

To calculate the sample size, we used the prevalence rate of complications of $2.7 \%$, found in the study by Propst et al. ${ }^{14}$ Considering a sample error of $2.5 \%$ and a level of significance of $5 \%$, the sample size should be composed of at least 162 women. Through a list provided by the Hospital Statistics Service, 4,826 hysteroscopy procedures were performed between March 1st, 2000 and June 28th, 2016. In the same period, 1,212 hospital admissions with International Classification of Diseases (ICD) corresponding to uterine myoma (D25.0, D25.1, D25.9) were identified. When performing the data crossing, we observed that 227 surgical hysteroscopy procedures were performed to treat myomas.

Later, using the hospital's computerized system, the surgical scales performed between August 1st, 2012 (date of the beginning of the use of the computerized system) and July 31st, 2017 were reviewed, and an additional 275 hysteroscopic procedures that were not present in the initial listing were identified. After a detailed evaluation of the medical records, 84 procedures were excluded from the analysis because they were not surgical hysteroscopies for the treatment of fibroids, making a total of 418 hysteroscopic procedures. For women who underwent more than one procedure, only the first procedure performed at the hospital was included in the analysis. Thus, the final sample consisted of 338 women (-Fig. 1).

Data collection was performed by the researcher in charge at the Medical and Statistical Archive Service of the hospital, after careful analysis of the medical records. The project was approved by the Ethics in Research Committee of UNICAMP under CAAE number: 61606216.1.0000.5404.

\section{Main Outcomes}

The main outcomes analyzed in the study were complete myomectomy in a single hysteroscopic procedure and the occurrence of early complications related to the procedure, defined as the presence of any of the following conditions: abnormal bleeding during the procedure; uterine perforation; false route (formation of a different path than the

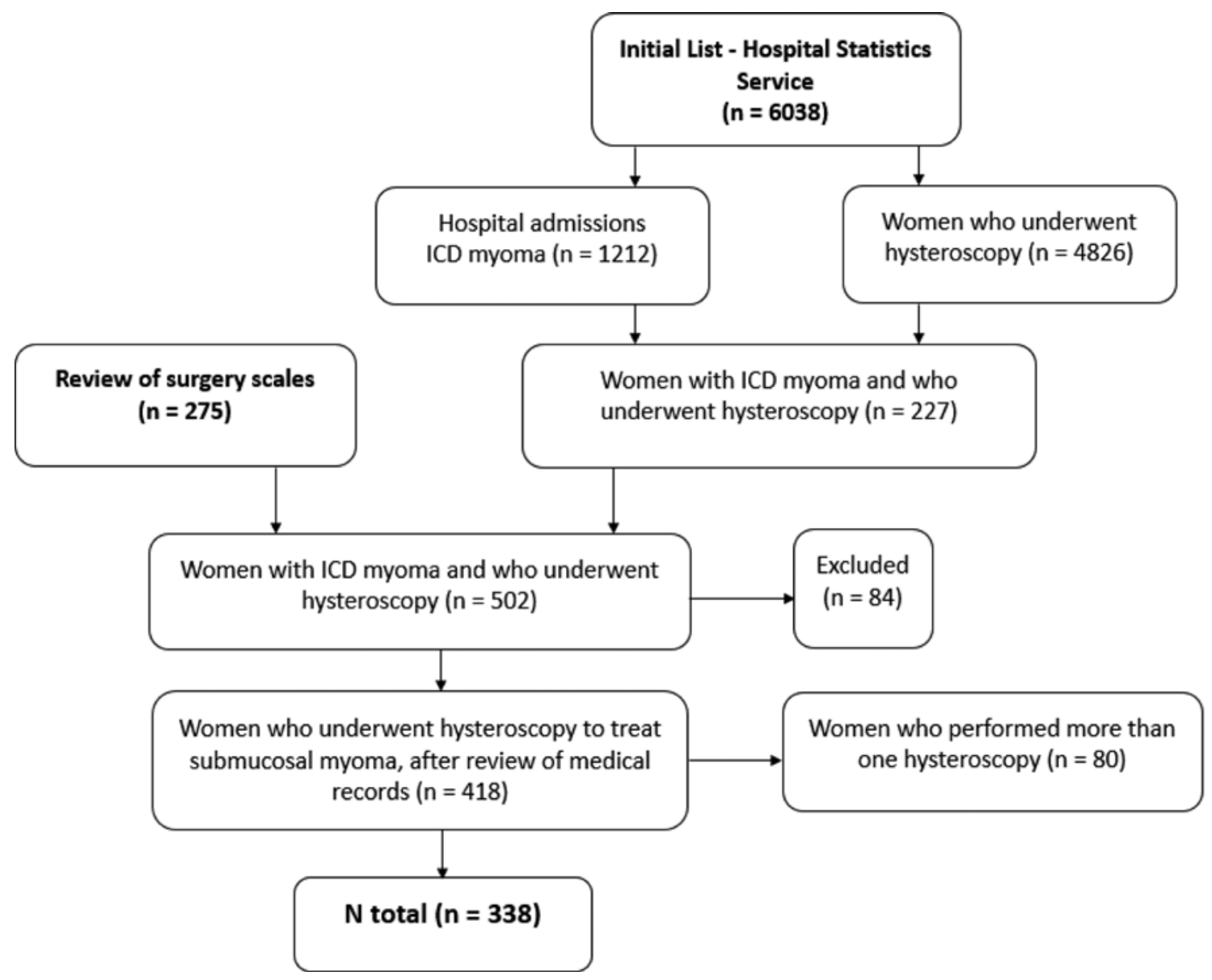

Fig. 1 Sample selection. 
cervical canal during the surgical procedure); fluid overload (occurrence of a deficit in the distension media distention greater than $1000 \mathrm{~mL}$ or serum sodium dosage lower than $125 \mathrm{mEq} /$ liter); need for blood transfusion; postoperative infection; and need for laparotomy to treat the complications in the same hospitalization. ${ }^{17}$

\section{Control Variables}

The control variables were: longest fibroid diameter in millimeters; fibroid location in the uterine cavity (anterior, posterior, lateral and cervical); International Federation of Gynecology and Obstetrics (FIGO) classification, ${ }^{18}$ based on the myometrial component, classified by hysteroscopy or ultrasonography $(0 / 1 / 2)$; number of submucous myomas; duration of the procedure in minutes; volume of the distention media used $(\mathrm{mL})$; water balance $(\mathrm{mL})$; indication for the hysteroscopy (abnormal uterine bleeding; infertility; pelvic pain; and abnormal routine-examination finding); result of the anatomopathological examination; age in years; weight $(\mathrm{kg})$; body mass index (BMI); skin color (white and nonwhite); number of pregnancies; number of vaginal deliveries; number of cesarean sections; number of abortions; menopausal status (premenopausal; postmenopausal); use of hormone therapy to treat menopausal symptoms for at least six consecutive months before surgery (yes/no); use of preoperative gonadotrophin-releasing hormone $(\mathrm{GnRH})$ analog medication for at least three consecutive months prior to surgery (yes/no); use of hormonal combined contraceptive estrogen and progesterone, orally, injected, transdermally or vaginally, for at least six consecutive months before surgery (yes/no); use of progesterone contraceptive alone, orally, injected or subdermally implanted for at least six consecutive months prior to surgery (yes/no); use of misoprostol to prepare the uterine cervix prior to surgery (yes/ no); diabetes mellitus (yes/no); arterial hypertension (yes/ no); and multimorbidity: presence of two or more chronic diseases (yes/no).

\section{Statistical Analysis}

A descriptive statistical analysis of the data was performed first. The continuous variables were expressed as mean, standard deviation, median, minimum and maximum values. The categorical variables were expressed as relative frequencies. Subsequently, bivariate analyses were performed to verify the association among the dependent variables "complete myomectomy in a single hysteroscopic procedure" and "presence of early complications related to the procedure" and the independent variables. For the categorical independent variables, the chi-squared or Fisher exact tests were performed; the Mann-Whitney test was performed for the continuous variables. Two models of Cox multiple regression were then developed using the Stepwise variable selection criterion to evaluate the factors independently associated with complete myomectomy and early complications related to the procedure. The level of significance was assumed at $5 \%$. The computer software used was
The Statistical Analysis System for Windows, version 9.2 (SAS Institute, Inc., Cary, NC, US). ${ }^{19-23}$

\section{Results}

In the evaluated period, we identified 338 women who underwent hysteroscopy for the treatment of uterine fibroids. The mean age of the women at the time of the procedure was $47.88( \pm 11.55)$ years, and the mean BMI was 28.80 ( \pm 5.93$)$. Most women were white $(73.43 \%)$. The mean number of pregnancies was $2.61( \pm 2.03)$, the mean number of vaginal deliveries was $1.46( \pm 1.89)$, and the mean number of cesarean deliveries was $0.81( \pm 1.05)$. In total, 118 (34.91\%) women were postmenopausal, $5.2 \%$ of whom were undergoing hormonal therapy to treat climacteric symptoms. A total of 220 (65.09\%) women were premenopausal, $70(20.7 \%)$ were using combined hormonal contraceptives, and $56(16.57 \%)$ were using progesterone-only contraceptive methods. Only 10 (2.96\%) women had previously used GnRH analogues. The most frequent comorbidities were hypertension 119 (35.31\%) and diabetes mellitus 42 (12.43\%). In 52 (15.38\%) of the procedures, the women had multimorbidity (more than two associated diseases) (-Table $\mathbf{1}$ ).

Most procedures (88.16\%) were performed between 2012 and 2017. The main surgical indication was bleeding in $78.7 \%$ of cases, and the second main indication was an incidental finding in a routine imaging exam (19.23\%). In $89.05 \%$ of the procedures, there was a single fibroid to be treated, in $8.58 \%$ of them, there were two fibroids to be treated, and in $2.37 \%$, there were 3 or more fibroids. The mean diameter of the largest fibroid was $2.62 \mathrm{~cm}( \pm 1.54 \mathrm{~cm})$, the smallest fibroid had $3 \mathrm{~mm}$, and the largest one had $8 \mathrm{~cm}$. According to the International Federation of Gynecology and Obstetrics (Fédération Internationale de Gynécologie et d'Obstétrique, FIGO, in French) most women (66.96\%) had fibroids classified as degree $0 ; 20.54 \%$ had grade- 1 fibroids, and $12.50 \%$ had grade- 2 fibroids. The most frequent location of the fibroids was the lateral wall (48.88\%), followed by the anterior wall (31.3\%), and the posterior wall (28.4\%). In 156 (46.15\%) of the procedures, misoprostol was used to prepare the uterine cervix. The mean duration of the surgery, after the resectoscope was introduced, was 30.96 minutes $( \pm 13.98)$, with a median of 30 minutes, a minimum time of 3 minutes, and a maximum time of 72 minutes (-Table $\mathbf{2}$ ).

The myomectomies were completed in 1 procedure in $63.31 \%$ of the cases ( 214 out of 338 ). In the bivariate analysis of the quantitative variables associated with complete myomectomy in a single hysteroscopic procedure, we found that women at an older age $(p<0.01)$, with a higher number of pregnancies $(p<0.01)$, a higher number of vaginal deliveries $(p<0.01)$, a higher weight $(p=0.04)$, with less fibroids $(p<0.01)$, with a lower mean diameter of the largest fibroid $(p<0.01)$, with shorter surgery duration $(p<0.01)$, and in which smaller solution volumes were used $(p<0.01)$ had complete myomectomy with a greater frequency ( - Table 3 ). In the bivariate analysis of the categorical variables associated with complete myomectomy in a single hysteroscopic procedure, we found that women with a lower FIGO 
480 Factors Associated with the Complications of Hysteroscopic Myomectomy Lima et al.

Table 1 Clinical and sociodemographic characteristics $(n=338)$

\begin{tabular}{|c|c|c|}
\hline Characteristics & Total & $\%$ \\
\hline \multicolumn{3}{|l|}{ Age (years) } \\
\hline$<40$ & 87 & 25.74 \\
\hline $40-59$ & 192 & 56.80 \\
\hline$>60-69$ & 59 & 17.46 \\
\hline \multicolumn{3}{|l|}{ Skin color* } \\
\hline White & 246 & 73.43 \\
\hline Non-white & 89 & 26.57 \\
\hline \multicolumn{3}{|c|}{ Body mass index $\left(\mathrm{kg} / \mathrm{m}^{2}\right)$} \\
\hline$<18.5$ & 4 & 1.18 \\
\hline $18.5-24.9$ & 82 & 24.26 \\
\hline $25-29.9$ & 138 & 40.83 \\
\hline$>30$ & 114 & 33.73 \\
\hline \multicolumn{3}{|c|}{ Number of pregnancies } \\
\hline 0 & 47 & 13.90 \\
\hline 1 & 59 & 17.46 \\
\hline$\geq 2$ & 232 & 68.64 \\
\hline \multicolumn{3}{|c|}{ Number of cesarian sections } \\
\hline 0 & 180 & 53.25 \\
\hline 1 & 82 & 24.26 \\
\hline$\geq 2$ & 76 & 22.49 \\
\hline \multicolumn{3}{|c|}{ Number of vaginal deliveries } \\
\hline 0 & 151 & 44.67 \\
\hline 1 & 61 & 18.05 \\
\hline$\geq 2$ & 126 & 37.28 \\
\hline \multicolumn{3}{|l|}{ Menopausal status } \\
\hline Premenopausal & 220 & 65.09 \\
\hline Postmenopausal & 118 & 34.91 \\
\hline \multicolumn{3}{|c|}{ Menopausal hormone therapy ${ }^{a}$} \\
\hline Yes & 6 & 5.22 \\
\hline No & 109 & 94.78 \\
\hline \multicolumn{3}{|c|}{ Combined hormonal contraceptives } \\
\hline Yes & 70 & 20.71 \\
\hline No & 268 & 79.29 \\
\hline \multicolumn{3}{|c|}{ Progesterone-only contraceptives } \\
\hline Yes & 56 & 16.57 \\
\hline No & 282 & 83.43 \\
\hline \multicolumn{3}{|c|}{ Gonadotrophin-releasing hormone analogues } \\
\hline Yes & 10 & 2.96 \\
\hline No & 328 & 97.04 \\
\hline \multicolumn{3}{|l|}{ Hypertension* } \\
\hline Yes & 119 & 35.31 \\
\hline No & 218 & 64.69 \\
\hline \multicolumn{3}{|l|}{ Diabetes mellitus } \\
\hline Yes & 42 & 12.43 \\
\hline No & 296 & 87.57 \\
\hline \multicolumn{3}{|l|}{ Multimorbidity } \\
\hline Yes & 52 & 15.38 \\
\hline No & 286 & 84.62 \\
\hline
\end{tabular}

Notes: *Missing data. ${ }^{\mathrm{a}}$ Among postmenopausal women.
Table 2 Characteristics of the hysteroscopic procedure $(n=338)$

\begin{tabular}{|c|c|c|}
\hline Characteristics & Total & $\%$ \\
\hline \multicolumn{3}{|l|}{ Main indication } \\
\hline Bleeding & 266 & 78.70 \\
\hline Incidental finding & 65 & 19.23 \\
\hline Infertility & 4 & 1.18 \\
\hline Pain & 3 & 0.89 \\
\hline \multicolumn{3}{|l|}{ Number of fibroids } \\
\hline 1 & 301 & 89.05 \\
\hline 2 & 29 & 8.58 \\
\hline$\geq 3$ & 8 & 2.37 \\
\hline \multicolumn{3}{|l|}{ FIGO classification ${ }^{a, b}$} \\
\hline 0 & 225 & 66.96 \\
\hline 1 & 69 & 20.54 \\
\hline 2 & 42 & 12.50 \\
\hline \multicolumn{3}{|l|}{ Location $^{a, c}$} \\
\hline Posterior wall & 89 & 25.95 \\
\hline Anterior wall & 98 & 28.57 \\
\hline Lateral wall & 153 & 44.61 \\
\hline Cervical & 3 & 0.87 \\
\hline \multicolumn{3}{|l|}{ Misoprostol } \\
\hline Yes & 156 & 46.15 \\
\hline No & 182 & 53.85 \\
\hline \multicolumn{3}{|c|}{ Anatomopathological finding } \\
\hline Leiomyoma & 286 & 84.62 \\
\hline Adenomyoma & 33 & 9.76 \\
\hline Lipoleiomyoma & 3 & 0.89 \\
\hline Endometrium & 1 & 0.30 \\
\hline No material & 15 & 4.44 \\
\hline
\end{tabular}

Abbreviation: FIGO, International Federation of Gynecology and Obstetrics (Fédération Internationale de Gynécologie et d'Obstétrique, in French). Notes: ${ }^{\mathrm{a}}$ Missing data. ${ }^{\mathrm{b}} \mathrm{Greatest}$ degree of penetration of the fibroids. 'Location of any fibroid; the women could have more than one fibroid in the uterine cavity.

classification of the largest myoma $(p<0.01)$, with a nonlocalized myoma in the anterior wall $(p=0.04)$, adenomyoma in the anatomopathological examination $(p<0.01)$, not using combined contraceptives $(p<0.01)$, no GnRH analogues prior to surgery $(p<0.01)$, postmenopausal $(p<0.01)$, with hypertension $(p=0.02)$, without excessive bleeding during the procedure $(p=0.01)$, without uterine perforation ( $p=0.02)$, without fluid overload $(p<0.01)$, and without early complications related to the procedure $(p<0.01)$ had a greater frequency of complete myomectomies ( - Table 4).

Throughout the analyzed period, 44 (13.01\%) women had early complications related to the hysteroscopic procedure: 15 (4.44\%) presented excessive bleeding during the procedure, 14 (4.14\%) had uterine perforation, 9 (2.66\%) had a false route, 6 
Factors Associated with the Complications of Hysteroscopic Myomectomy Lima et al. 481

Table 3 Distribution of some quantitative variables according to complete myomectomy and early complications in women undergoing surgical hysteroscopy $(n=338)$

\begin{tabular}{|c|c|c|c|c|c|c|}
\hline & \multicolumn{2}{|c|}{$\begin{array}{l}\text { Complete myomectomy - } \\
\text { mean (standard deviation) }\end{array}$} & \multirow[t]{2}{*}{$p$-value ${ }^{*}$} & \multicolumn{2}{|c|}{$\begin{array}{l}\text { Early complications - mean } \\
\text { (standard deviation) }\end{array}$} & \multirow[t]{2}{*}{$p$-value* } \\
\hline & Yes & No & & Yes & No & \\
\hline Age (years) & $49.64(11.13)$ & $44.83(11.66)$ & $<0.01$ & $47.93(12.44)$ & $47.87(11.43)$ & 0.72 \\
\hline Pregnancies & $2.85(2.05)$ & $2.19(1.92)$ & $<0.01$ & $2.05(1.84)$ & $2.69(2.04)$ & 0.02 \\
\hline Vaginal deliveries & $1.66(1.94)$ & $1.10(1.75)$ & $<0.01$ & $0.98(1.73)$ & $1.53(1.91)$ & 0.02 \\
\hline Weight $(\mathrm{kg})$ & $74.12(14.63)$ & 71.62 (16.87) & 0.04 & $72.16(15.98)$ & $73.36(15.47)$ & 0.64 \\
\hline Number of fibroids & $1.09(0.34)$ & $1.24(0.63)$ & $<0.01$ & $1.20(0.51)$ & $1.14(0.47)$ & 0.25 \\
\hline $\begin{array}{l}\text { Mean diameter of the } \\
\text { largest fibroid }(\mathrm{mm})\end{array}$ & $21.66(12.29)$ & $36.15(15.84)$ & $<0.01$ & $32.02(15.78)$ & $26.22(15.18)$ & 0.02 \\
\hline Duration of the procedure (minutes) & $29.36(13.16)$ & $33.73(14.95)$ & $<0.01$ & $33.00(18.18)$ & $30.66(13.25)$ & 0.55 \\
\hline Volume of the distension media (ml) & $\begin{array}{l}102.80 \\
(1024.90)\end{array}$ & $\begin{array}{l}689.52 \\
(2587.20)\end{array}$ & $<0.01$ & $\begin{array}{l}647.73 \\
(2591.50)\end{array}$ & $\begin{array}{l}268.71 \\
(1631.4)\end{array}$ & 0.20 \\
\hline
\end{tabular}

Note: *Mann-Whitney test.

Table 4 Categorical variables associated with complete myomectomy and early complications in women undergoing surgical hysteroscopy ( $n=338)$

\begin{tabular}{|c|c|c|c|c|c|c|c|c|}
\hline & \multicolumn{2}{|c|}{$\begin{array}{l}\text { Complete myo- } \\
\text { mectomy (\%) }\end{array}$} & \multirow[t]{2}{*}{$\mathrm{n}$} & \multirow[t]{2}{*}{$p$-value } & \multicolumn{2}{|c|}{$\begin{array}{l}\text { Early complica- } \\
\text { tion (\%) }\end{array}$} & \multirow[t]{2}{*}{$\mathrm{n}$} & \multirow[t]{2}{*}{$p$-value } \\
\hline & Yes & No & & & Yes & No & & \\
\hline FIGO classification of the largest fibroid* & & & & $<0.01^{a}$ & & & & $0.96^{\mathrm{a}}$ \\
\hline 0 & 71.56 & 28.44 & 225 & & 13.33 & 86.67 & 225 & \\
\hline 1 & 53.62 & 46.38 & 69 & & 13.04 & 86.96 & 69 & \\
\hline 2 & 33.33 & 66.67 & 42 & & 88.10 & 11.90 & 42 & \\
\hline Anterior-wall fibroid* & & & & $0.04^{\mathrm{a}}$ & & & & $0.62^{a}$ \\
\hline Yes & 56.12 & 43.88 & 98 & & 10.20 & 89.80 & 98 & \\
\hline No & 67.90 & 32.10 & 215 & & 12.09 & 87.91 & 215 & \\
\hline Anatomopathological finding & & & & $<0.01^{\mathrm{b}}$ & & & & $0.40^{\mathrm{b}}$ \\
\hline Leiomyoma & 63.63 & 36.37 & 286 & & 11.19 & 88.81 & 286 & \\
\hline Adenomyoma & 93.94 & 6.06 & 33 & & 9.09 & 90.91 & 33 & \\
\hline Other & 5.26 & 94.74 & 19 & & 47.37 & 52.63 & 19 & \\
\hline Combined hormonal contraceptives & & & & $<0.01^{\mathrm{a}}$ & & & & $0.96^{\mathrm{a}}$ \\
\hline Yes & 47.14 & 52.86 & 70 & & 12.86 & 87.14 & 70 & \\
\hline No & 67.54 & 32.46 & 268 & & 13.06 & 86.94 & 268 & \\
\hline Misoprostol & & & & $0.33^{\mathrm{a}}$ & & & & $0.23^{\mathrm{a}}$ \\
\hline Yes & 66.02 & 33.98 & 156 & & 15.38 & 84.62 & 156 & \\
\hline No & 60.99 & 39.01 & 182 & & 10.99 & 89.01 & 182 & \\
\hline Progesterone-only contraceptives & & & & $0.17^{\mathrm{a}}$ & & & & $0.04^{\mathrm{a}}$ \\
\hline Yes & 55.36 & 44.64 & 56 & & 21.43 & 78.57 & 56 & \\
\hline No & 64.90 & 35.10 & 282 & & 11.35 & 88.65 & 282 & \\
\hline Gonadotrophin-releasing hormone analogue & & & & $<0.01^{\mathrm{b}}$ & & & & $0.62^{\mathrm{b}}$ \\
\hline Yes & 0.00 & 100.00 & 10 & & 20.00 & 80.00 & 10 & \\
\hline No & 65.24 & 34.76 & 328 & & 12.80 & 87.20 & 328 & \\
\hline Menopausal status & & & & $<0.01^{\mathrm{a}}$ & & & & $0.37^{\mathrm{a}}$ \\
\hline Postmenopausal & 75.42 & 24.58 & 118 & & 15.25 & 84.75 & 118 & \\
\hline Premenopausal & 56.82 & 43.18 & 220 & & 11.82 & 88.18 & 220 & \\
\hline
\end{tabular}


482 Factors Associated with the Complications of Hysteroscopic Myomectomy Lima et al.

Table 4 (Continued)

\begin{tabular}{|c|c|c|c|c|c|c|c|c|}
\hline & \multicolumn{2}{|c|}{$\begin{array}{l}\text { Complete myo- } \\
\text { mectomy (\%) }\end{array}$} & \multirow[t]{2}{*}{$\mathrm{n}$} & \multirow[t]{2}{*}{$p$-value } & \multicolumn{2}{|c|}{$\begin{array}{l}\text { Early complica- } \\
\text { tion (\%) }\end{array}$} & \multirow[t]{2}{*}{$\mathrm{n}$} & \multirow[t]{2}{*}{$p$-value } \\
\hline & Yes & No & & & Yes & No & & \\
\hline Hypertension & & & & $0.02^{a}$ & & & & $0.40^{\mathrm{a}}$ \\
\hline Yes & 71.43 & 28.57 & 119 & & 15.13 & 84.87 & 119 & \\
\hline No & 59.17 & 40.83 & 218 & & 11.93 & 88.07 & 218 & \\
\hline Excessive bleeding & & & & $0.01^{\mathrm{a}}$ & & & & - \\
\hline Yes & 33.33 & 66.67 & 15 & & - & - & - & \\
\hline No & 64.71 & 35.29 & 323 & & - & - & - & \\
\hline Uterine perforation & & & & $0.02^{\mathrm{a}}$ & & & & - \\
\hline Yes & 35.71 & 64.29 & 14 & & - & - & - & \\
\hline No & 64.51 & 35.49 & 324 & & - & - & - & \\
\hline Fluid overload & & & & $<0.01^{\mathrm{b}}$ & & & & - \\
\hline Yes & 0.00 & 100.00 & 6 & & - & - & - & \\
\hline No & 64.46 & 35.54 & 332 & & - & - & - & \\
\hline Early complication & & & & $<0.01^{\mathrm{a}}$ & & & & - \\
\hline Yes & 34.09 & 65.91 & 44 & & - & - & - & \\
\hline No & 67.69 & 32.31 & 294 & & - & - & - & \\
\hline Complete myomectomy & & & & - & & & & $<0.01^{\mathrm{a}}$ \\
\hline Yes & - & - & - & & 7.01 & 92.99 & 214 & \\
\hline No & - & - & - & & 23.39 & 76.61 & 124 & \\
\hline
\end{tabular}

Abbreviation: FIGO, International Federation of Gynecology and Obstetrics (Fédération Internationale de Gynécologie et d’Obstétrique, in French). Notes: ${ }^{a}$ Chi-square test. ${ }^{\text {b}}$ Fisher exact test. ${ }^{*}$ Missing data.

(1.78\%) presented fluid overload, 2 (0.59\%) underwent laparotomy, and $1(0.3 \%)$ had a postoperative infection. No woman needed blood transfusion after the procedure. In the bivariate analysis of the variables associated with early complications, we found that women with fewer pregnancies $(p=0.02)$, a lower number of vaginal deliveries $(p=0.02)$, fibroids with longer diameters $(p=0.04)$, with incomplete myomectomy $(p<0.01)$, and who used progesterone-only contraceptives $(p=0.04)$ had early complications with a higher frequency (-Tables 3 and $\mathbf{4}$ ).
In the final statistical model using the multiple Cox regression, we observed that the factors independently associated with complete myomectomy in a single hysteroscopic procedure were the diameter of the largest fibroid in millimeters (PR: 0.97; 95\%CI: 0.96-0.98) and fibroid FIGO classification 0 (PR: 2.04; 95\%CI: 1.18-3.52). The only independent factor associated with the occurrence of early complications was incomplete myomectomy (PR: 2.77; 95\%CI: 1.43-5.38) (- Table 5).

Table 5 Variables associated with complete myomectomy and early complications - Multiple Cox Regression ( $n=313)$

\begin{tabular}{lllll}
\hline & Categories & p-value & PR & 95\%Cl (PR) \\
\hline $\begin{array}{l}\text { Complete myomectomy } \\
\text { Largest fibroid diameter }\end{array}$ & Continuous variable (mm) & $<0.01$ & 0.97 & $0.96-0.98$ \\
FIGO classification & 2 (ref) & - & 1.00 & - \\
& 1 & 0.10 & $0.91-3.10$ \\
& 0 & 0.01 & 2.04 & $1.18-3.52$ \\
Early complications $^{\mathrm{b}}$ & & - & 1.00 & - \\
Complete myomectomy $^{\text {Yes (ref) }}$ & No & $<0.01$ & 2.77 & $1.43-5.38$ \\
\hline
\end{tabular}

Abbreviation: 95\%Cl, 95\% confidence interval; FIGO, International Federation of Gynecology and Obstetrics (Fédération Internationale de Gynécologie et d'Obstétrique, in French); PR, prevalence ratio; ref, reference level.

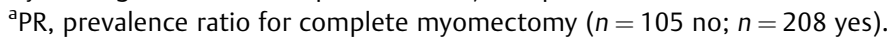

${ }^{b} P R$, prevalence ratio for early complications ( $n=277$ no; $n=36$ yes); $95 \% \mathrm{Cl} P R=95 \%$ confidence interval for the prevalence ratio. Stepwise criteria for variable selection. 


\section{Discussion}

Submucosal myomas represent $5 \%$ to $10 \%$ of all myomas. ${ }^{24}$ Hysteroscopic myomectomy is the treatment of choice, but among the hysteroscopic procedures, it is the one with the highest complication rates. ${ }^{14}$ Our objective was to identify the factors related to the possibility of complete myomectomy in a single surgical procedure, in addition to identifying the possible factors associated with a higher frequency of early complications resulting from the procedure.

In the present study, we found a complete myomectomy rate of $63.31 \%$, which is lower than the one reported by Mazzon et $\mathrm{al}^{15}$ in 2015, which was of $87.62 \%$. However, in their study, Mazzon et $\mathrm{al}^{15}$ included only women with single fibroids. In the present study, $\sim 10 \%$ of the women had more than one submucosal fibroid to be treated, which may justify the difference observed. In 2008, Murakami et al ${ }^{25}$ reported a complete myomectomy rate of $57.1 \%$; however, the authors included only women with fibroids of degrees 1 and 2 according to the FIGO classification. These fibroids are technically more difficult to be resected in comparison to pediculate fibroids (grade 0 ), which impairs the comparison between the studies.

We observed that the factors independently associated with complete myomectomy in a single surgical time were the fibroid diameter and the degree of penetration in the myometrium. With each $1-\mathrm{mm}$ increase in myoma diameter, the chance of complete myomectomy decreased by 2.4\%; in addition, women with fibroids classified as FIGO grade 0 had twice the chance of having a complete myomectomy compared with women with FIGO grade-2 fibroids. Our data are in agreement with that of other studies on the subject. Wamsteker et $\mathrm{al}^{18}$ conducted a prospective study with 51 women with submucosal fibroids and increased bleeding, and they concluded that myomas with greater myometrial penetration would have less chance of complete resection, requiring multiple procedures to improve the symptoms. In addition, fibroids with a larger intramural component generally have a larger diameter and volume, which increases the complexity of the procedure, reducing the probability of complete myomectomy in a single surgical time. ${ }^{6}$

We did not observe an association between the previous use of GnRH analogues and a greater frequency of complete myomectomies. In contrast, no woman who had previously used GnRH analogues had a complete myomectomy in a single surgical time. This finding is probably due to the fact that even after using GnRH analogues, the women had fibroids larger than the general mean (the mean overall diameter was $2.6 \mathrm{~cm}$, and the mean diameter in women who had used $\mathrm{GnRH}$ analogues was $4.9 \mathrm{~cm}$ ). Similarly, in the randomized controlled trial by Favilli et $\mathrm{al}^{26}$ prior use of $\mathrm{GnRH}$ analogues did not facilitate the complete removal of grade- 2 submucosal fibroids and increased the surgical time. In addition, we did not find any independent association between contraceptive use (combined or progesterone-only) and complete myomectomy or early complications.
In the present study, early complications were observed in $13.02 \%$ of the procedures, a rate similar to that found by Propst et $\mathrm{al}^{14}$ who reported a $14 \%$ complication rate in hysteroscopic myomectomies. Of all early complications we observed, the majority (4.44\% of the cases) was excessive bleeding during the procedure. The classification of excessive bleeding was based on the reports described in the medical records, which are subject to bias. The quantification of the bleeding volume in the procedure is difficult to perform accurately. A fact that corroborates this finding is that, despite the report of excessive bleeding in the description of the surgery, no women required blood transfusion. Not all women had their hemoglobin levels measured before and after the procedure, which made it impossible to use this parameter in the analysis. The second and third most frequent complications were uterine perforation $(4.14 \%)$ and false route $(2.66 \%)$. Of the uterine perforations, 6 were at dilation of the uterine cervix. In a randomized controlled trial, Preutthipan and Herabutya ${ }^{27}$ concluded that the use of vaginal misoprostol may prevent the risk of uterine perforation. However, in our study, the use of misoprostol was not associated with fewer complications, and was not associated with the complete resection of fibroids. A recent clinical trial $^{28}$ also evaluated the use of misoprostol as a method of cervical preparation, but prior to the performance of the diagnostic hysteroscopy in postmenopausal women. The authors concluded that in addition to misoprostol not reducing the intensity of the pain, the duration of the procedure and the need for additional cervical dilatation, there was a higher incidence of adverse events, such as vaginal bleeding, cramps and diarrhea among medication users. ${ }^{28}$

Fluid overload can occur through direct passage of fluid through the uterine vessels that are opened during surgery or through the entry of fluid into the peritoneal cavity, either through the uterine tubes or through uterine perforation. ${ }^{29}$ In the present study, the only distension medium used was $1.5 \%$ glycine, and 6 women presented with fluid overload (1.78\%). Among them, none had uterine perforation. In a Dutch multicenter study, ${ }^{13}$ the authors identified 5 cases of fluid overload in 2,515 surgical hysteroscopies (0.2\%), although, in that study, only $35 \%$ of the health facilities were teaching hospitals, which could partly explain the difference in fluid overload rates.

The present study has some limitations. Since it is a cross-sectional study, it is not possible to establish cause and effect associations. We could not use the size, topography, extension, penetration, wall (STEPW) classification proposed by Lasmar et al, ${ }^{30,31}$ because we did not have access to data regarding the extent of the myoma base in relation to the uterine wall. The classification adopted by the FIGO was used to classify the myometrial component, which is currently more widespread and used than the STEPW classification. ${ }^{18}$ Although we did not use the STEPW classification, we did not observe an association between the location of the myoma in the uterine cavity and a greater frequency of incomplete myomectomies or early complications. The fact that the only independent factor associated with the occurrence of early complications was 
incomplete myomectomy is probably an interpretation bias. Since the diameter of the fibroid and the degree of penetration in the myometrium are independently associated with a complete myomectomy, they are also probably associated with the occurrence of early complications. The trend of evolution and dissemination of minimally-invasive technologies contributed to the increase in the number of hysteroscopies performed during the analyzed period; however, since 2012 the surgical information control was completely computerized, which may have contributed to an easier identification of women undergoing hysteroscopic myomectomy starting that year.

\section{Conclusion}

In conclusion, our results corroborate the fact that the main factor associated with complications in the hysteroscopic myomectomy procedure is the myoma itself. No other characteristic, whether intrinsic to the women, such as age, skin color, parity and presence of comorbidities, or even treatment-related characteristics, such as use of GnRH analogues, misoprostol or hormonal contraceptives, was associated with a higher frequency of incomplete myomectomies or early complications. Women with larger fibroids and with a high degree of myometrial penetration have a greater chance of developing complications of hysteroscopic myomectomy.

\section{Contributors}

All of the authors contributed with the project and data interpretation, the writing of the article, the critical review of the intellectual content, and with the final approval of the version to be published.

\section{Conflict of Interests}

The authors have no conflict of interests to declare.

\section{References}

1 Bulun SE. Uterine fibroids. N Engl J Med. 2013;369(14):1344-1355. Doi: 10.1056/NEJMra1209993

2 Linder D, Gartler SM. Glucose-6-phosphate dehydrogenase mosaicism: utilization as a cell marker in the study of leiomyomas. Science. 1965;150(3692):67-69. Doi: 10.1126/science.150.3692.67

3 Wong L, Brun JL. Myomectomy: technique and current indications. Minerva Ginecol. 2014;66(01):35-47

4 Baird DD, Dunson DB, Hill MC, Cousins D, Schectman JM. High cumulative incidence of uterine leiomyoma in black and white women: ultrasound evidence. Am J Obstet Gynecol. 2003;188 (01):100-107. Doi: 10.1067/mob.2003.99

5 Parker WH, Fu YS, Berek JS. Uterine sarcoma in patients operated on for presumed leiomyoma and rapidly growing leiomyoma. Obstet Gynecol. 1994;83(03):414-418

6 Emanuel MH. Hysteroscopy and the treatment of uterine fibroids. Best Pract Res Clin Obstet Gynaecol. 2015;29(07):920-929. Doi: 10.1016/j.bpobgyn.2015.03.014

7 Indman PD. Hysteroscopic treatment of submucous myomas. Clin Obstet Gynecol. 2006;49(04):811-820. Doi: 10.1097/01. grf.0000211960.53498.29

8 Salim S, Won H, Nesbitt-Hawes E, Campbell N, Abbott J. Diagnosis and management of endometrial polyps: a critical review of the literature. J Minim Invasive Gynecol. 2011;18(05):569-581. Doi: 10.1016/j.jmig.2011.05.018

9 Camanni M, Bonino L, Delpiano EM, Ferrero B, Migliaretti G, Deltetto F. Hysteroscopic management of large symptomatic submucous uterine myomas. J Minim Invasive Gynecol. 2010; 17(01):59-65. Doi: 10.1016/j.jmig.2009.10.013

10 Aas-Eng MK, Langebrekke A, Hudelist G. Complications in operative hysteroscopy - is prevention possible? Acta Obstet Gynecol Scand. 2017;96(12):1399-1403. Doi: 10.1111/aogs.13209

11 Goldstein SR. Significance of incidentally thick endometrial echo on transvaginal ultrasound in postmenopausal women. Menopause. 2011;18(04):434-436. Doi: 10.1097/gme.0b013e31820ad00b

12 Aydeniz B, Gruber IV, Schauf B, Kurek R, Meyer A, Wallwiener D. A multicenter survey of complications associated with 21,676 operative hysteroscopies. Eur J Obstet Gynecol Reprod Biol. 2002;104(02):160-164. Doi: 10.1016/s0301-2115(02)00106-9

13 Jansen FW, Vredevoogd CB, van Ulzen K, Hermans J, Trimbos JB, Trimbos-Kemper TC. Complications of hysteroscopy: a prospective, multicenter study. Obstet Gynecol. 2000;96(02):266-270. Doi: 10.1016/s0029-7844(00)00865-6

14 Propst AM, Liberman RF, Harlow BL, Ginsburg ES. Complications of hysteroscopic surgery: predicting patients at risk. Obstet Gynecol. 2000;96(04):517-520. Doi: 10.1016/s0029-7844(00) 00958-3

15 Mazzon I, Favilli A, Grasso M, Horvath S, Bini V, Di Renzo GC, et al. Predicting success of single step hysteroscopic myomectomy: A single centre large cohort study of single myomas. Int J Surg. 2015;22:10-14. Doi: 10.1016/j.ijsu.2015.07.714

16 Andrade CM Junior, Diniz DBFQ, Lopes RGC. Preparo, técnica, e riscos da cirurgia histeroscópica com ressectoscópio. In: Crispi CP, Oliveira FMM, Damian Junior JC, Oliveira MAP, Ribeiro PAG. Tratado de endoscopia ginecológica: cirurgia minimamente invasiva. 3a ed. Rio de Janeiro: Revinter; 2012:543-549

17 Munro MG. Complications of hysteroscopic and uterine resectoscopic surgery. Obstet Gynecol Clin North Am. 2010;37(03): 399-425. Doi: 10.1016/j.ogc.2010.05.006

18 Munro MG, Critchley HO, Broder MS, Fraser IS; FIGO Working Group on Menstrual Disorders. FIGO classification system (PALMCOEIN) for causes of abnormal uterine bleeding in nongravid women of reproductive age. Int J Gynaecol Obstet. 2011;113 (01):3-13. Doi: 10.1016/j.ijgo.2010.11.011

19 Conover WJ. Practical nonparametric statistics. 3rd ed. New York: John Wiley \& Sons; 1999

20 Fleiss JL, Levin B, Paik MC. Statistical methods for rates and proportions. 3rd ed. Hoboken: John Wiley \& Sons; 2003

21 Hosmer DW, Lemeshow SL. Applied logistic regression. New York: John Wiley \& Sons; 1989

22 Siegel S, Castellan NJ Jr. Estatística não paramétrica para ciências do comportamento. 2a ed. Porto Alegre. Art Med. 2006

23 Tabachnick BG, Fidell LS. Using multivariate statistics. 4th ed. Boston: Allyn and Bacon; 2001

24 Di Spiezio Sardo A, Mazzon I, Bramante S, Bettocchi S, Bifulco G, Guida M, et al. Hysteroscopic myomectomy: a comprehensive review of surgical techniques. Hum Reprod Update. 2008;14(02): 101-119. Doi: 10.1093/humupd/dmm041

25 Murakami T, Hayasaka S, Terada Y, Yuki H, Tamura M, Yokomizo R, et al. Predicting outcome of one-step total hysteroscopic resection of sessile submucous myoma. J Minim Invasive Gynecol. 2008;15 (01):74-77. Doi: 10.1016/j.jmig.2007.08.597

26 Favilli A, Mazzon I, Grasso M, Horvath S, Bini V, Di Renzo GC, et al. Intraoperative effect of preoperative gonadotropin-releasing hormone analogue administration in women undergoing cold loop hysteroscopic myomectomy: a randomized controlled trial. J Minim Invasive Gynecol. 2018;25(04):706-714. Doi: 10.1016/j. jmig.2017.11.011

27 Preutthipan S, Herabutya Y. Vaginal misoprostol for cervical priming before operative hysteroscopy: a randomized controlled 
trial. Obstet Gynecol. 2000;96(06):890-894. Doi: 10.1016/s00297844(00)01063-2

28 Nakano FY, Yela DA, Pinto JPL, Riegas T, Benetti-Pinto CL, Pedro $\mathrm{AO}$, et al. Efficacy of misoprostol before diagnostic hysteroscopy in postmenopausal women: a randomized clinical trial. Menopause. 2018;25(07):789-794. Doi: 10.1097/GME.0000000000001074

29 McGurgan PM, Mcllwaine P. Complications of hysteroscopy and how to avoid them. Best Pract Res Clin Obstet Gynaecol. 2015;29 (07):982-993. Doi: 10.1016/j.bpobgyn.2015.03.009
30 Lasmar RB, Xinmei Z, Indman PD, Celeste RK, Di Spiezio Sardo A. Feasibility of a new system of classification of submucous myomas: a multicenter study. Fertil Steril. 2011;95(06):2073-2077. Doi: 10.1016/j.fertnstert.2011.01.147

31 Lasmar RB, Lasmar BP, Celeste RK, da Rosa DB, Depes DdeB, Lopes RGC. A new system to classify submucous myomas: a Brazilian multicenter study. J Minim Invasive Gynecol. 2012;19(05): 575-580. Doi: 10.1016/j.jmig.2012.03.026 